\title{
Multilevel Analysis: Biopsychosocial Determinants and Environmental Factor on the Incidence of Diarrhea Among Children Under Five in Surakarta
}

\author{
Erick Zicof ${ }^{1)}$, Setyo Sri Rahardjo²), Bhisma Murti1) \\ 1)Master Program In Public Health, Universitas Sebelas Maret \\ ${ }^{2)}$ Faculty of Medicine, Universitas Sebelas Maret
}

\begin{abstract}
Background: Diarrhea is an endemic disease with a potentialto become epidemicin Indonesia. Diarrhea most often occurs in children under five years of age. This study aimed to determine the relationship between biopsychosocial factors, environmental factor, and diarrhea occurrence in Surakarta, Central Java, using multilevel analysis.

Subjects and Method: This was an observational analytic study with a cross-sectional approach. This study was conducted on October 2017 - April 2018. A sample of 200 children under five years of age was selected by fixed disease sampling, consisting of 100 children with diarrhea and 100 without diarrhea. The dependent variable was the incidence of diarrhea. The independent variables were the number of family members, maternal knowledge, maternal personal hygiene, and environmental sanitation. The data were collected by questionnaire and analyzed by multilevel logistic regression in Stata 13.

Results: The number of family member $(b=1.09 ; 95 \% \mathrm{CI}=0.02$ to $2.15 ; \mathrm{p}<0.046)$ increased the risk of diarrhea. Good maternal knowledge $(b=-2.30 ; 95 \% \mathrm{CI}=-3.46$ to $-1.14 ; \mathrm{p}<0.001)$, good maternal personal hygiene $(b=-2.09 ; 95 \% \mathrm{CI}=-3.48$ to-0.70; $\mathrm{p}<0.003)$, and good environmental sanitation $(\mathrm{b}=-1.64 ; 95 \% \mathrm{CI}=-2.84$ to $-0.43 ; \mathrm{p}=0.008)$ decreased the risk of diarrhea in children under five. Village had a substantial contextual effect on the incidence of diarrhea with ICC= $66.14 \%$.

Conclusion: The number of family member increases the risk of diarrhea. Good maternal knowledge, good maternal personal hygiene, and good environmental sanitation decrease the risk of diarrhea in children under five. Village has a substantial contextual effect on the incidence of diarrhea
\end{abstract}

Keywords: diarrhea, number of family member, maternal knowledge, maternal personal hygiene, village, contextual effect

\section{Correspondence:}

Erick Zicof. Masters Program in Public Health, Universitas Sebelas Maret, Jl. Ir. Sutami No. 36 A, Surakarta, Indonesia. Email: erickzicof@gmail.com. Mobile: +6281363425870.

\begin{tabular}{l} 
BACKGROUND \\
\hline Diarrheal is the second leading cause of \\
death in infants and kills approximately \\
525,000 toddlers annually worldwide. \\
Globally, there are nearly 1.7 billion cases of \\
diarrhea in toddlers every year. Each \\
episode of diarrhea will result in the loss of \\
nutrients needed by children to grow, so \\
diarrhea is a major cause of malnutrition in \\
children under five (WHO, 2017). Based on
\end{tabular} data of Centers for Disease Control and Prevention (2015) there are 2,195 children die every day due to diarrhea. Diarrheal disease causes 1 among 9 toddlers deaths worldwide.

Diarrhea is an endemic disease in Indonesia and is also a potential illness of outbreaks (KLB) that often leads to death. Most diarrhea patientsare children under five years (toddlers). In 2015, there were 18 
outbreaks of Diarrhea in 11 provinces, 18 districts/cities, with 1,213 people and 30 deaths with Case Fatality Rate (CFR) of $2.47 \%$. Poor sanitation conditions will have negative impacts in many aspects of life, ranging from the decline in the quality of the community's environment, pollution of drinking water sources to the community, the increasing number of diarrhea and the emergence of several diseases (Ministry of health, 2016). According to the data of Indonesia Health Profile 2016, it is estimated that the number of diarrhea patients in health facilities is $6,897,463$ people, while the number of diarrhea patients reported which are handled in health facilities are $2,544,084$ people or $36.9 \%$ (Ministry of Health RI, 2017).

Some factors that trigger the occurrence of diarrhea are the provision of clean water, family latrines, waste processing, waste water management and personal hygiene (Fauziah al., 2016). In addition to environmental sanitation factors, personal factors of maternal hygiene are also very influential on the incidence of diarrhea in infants. Mother's behavior contributes to the increaseof diarrhea cases in infants. Mother is the closest person to a toddler who takes care of all the needs such as bathing, preparing and providing food and drink. Unhygienic mothers' behaviors such as not washing hands while feeding children, not cooking and cooking utensils can cause toddlers to be affected by diarrhea (Maharani and Yusiana, 2013).

Biopsychosocial concept is a concept that involves the interaction between biological, psychological and social factors in an effort to understand the process of a sickness and illness of a person and view the mind and body as a whole. The concept of biopsychosocial brings the notion that the condition of pain is not only in terms of physical medicine but also of the psycho- logical conditions that are influenced by environmental factors (Andri, 2011). The biopsychosocial approach systematically considers the biological, psychological, and social factors and complex interactions in understanding the health problems including diarrhea (Lowe et al., 2016).

Based on Central Java Provincial Health Profile (2016) data, the proportion of cases of diarrhea in 2016 was $68.9 \%$, it increased compared to the proportion of 2015 which was at $67.7 \%$. In Central Java Province, the achievement of population with access to proper sanitation in 2016 was $77.60 \%$, it was lower than the achievement in 2015 which was $78.70 \%$. The percentage of total community based sanitation village (STBM) in 2016 was $62.7 \%$, it slightly increased compared to that in 2015 which was $61.4 \%$. Data on the study of clean and healthy living behavior (PHBS) in the household order reported by District Health Office in Central Java in 2016 percentage of households were $44.03 \%$, it has decreased compared to that in 2015 which was $46.45 \%$.

The number of diarrhea patients in Surakarta City which was handled in 2016 was 11,183 people, most cases occurred in banjarsari sub district for about 4,211 people, followed by laweyan sub district for about 2.136 people and jebres district for about 1892 people. Surakarta is the lowest percentage of the implementation of STBM which was $3.9 \%$ in 2016 . The percentage of population with decent sanitation access is $61.7 \%$ and the coverage of clean and healthy living (PHBS) is $74.2 \%$ (Surakarta City Health Office 2017).

\section{SUBJECTS AND METHOD}

\section{Study design}

This was an analytic observational study with a cross sectional design. The study was 
conducted in Surakarta, Central Java, Indonesia, in October 2017 - april 2018.

\section{Population dan sample}

The population source in this study was toddlers in Banjarnegara regency. A sample of 200 children comprising 8 children from each village by fixed disease sampling.

\section{Study variables}

The dependent variable was diarrhea. The independent variables were family size, maternal knowledge, maternal healthy behavior, and environmental sanitation.

\section{Operational definition of variables}

The incidence of diarrhea is described as a condition of bowel discharge 3 times or more per day in infants with consistency of soft or liquid stool.

The number of family members was defined as how many people in a family. The measurement scale was continuous.

Maternal knowledge was defined as things that the mother knows about diarrhea in children under five including the definition, causes, symptoms, prevention and treatment. The measurement scale was continuous.

Maternal healthy behavior was defined as a mother's behavior that can cause diarrhea in infants. The measurement scale was continuous.

Environmental sanitation was defined as the condition of the maternal residence which includes the availability of sanitation facilities such as toilet, clean water source, dustbin, and sewerage channel. The measurement scale was continuous.

\section{Study Instruments}

The data about the number of family members, mother's knowledge and behavior were obtained using questionnaires. The environmental sanitation data were obtained using an observation sheet. The data of urban village standby stratum was obtained based on the annual report of City Health Office.

\section{Data analysis}

Univariate analysis was done to see the frequency distribution and percentage characteristics of research subjects. Bivariate analysis was done to study the relationship between diarrhea occurrence and independent variables using chi-square test and odds ratio calculation (OR) with confidence level (CI) of 95\%. Furthermore multivariate analysis was done using logistic regression through multilevel approach.

\section{Research ethics}

The research ethics included informed consent, anonymity, confidentiality and ethical clearance. Ethical clearance in this study was conducted at Dr. Moewardi hospital, Surakarta.

\section{RESULTS}

\section{The Characteristics of Subjects}

Distribution frequency characteristic of children was described in table 1.

Table 1 shows that the proportion of children under five who experienced the highest incidence of diarrhea in the age group $<24$ months was 42 children (66.7\%), the age proportion of children who did not experience the highest incidence of diarrhea in the age group $\geq 24$ months was 79 people $(57.7 \%)$. Most of the educational level of mothers whose children did not experience diarrhea were senior high school graduate for about 61 people (57\%), while mothers whose children suffer diarrhea mostly had education level < Senior high school for about 54 people (58.1\%). Most of the income of the family which the children did not suffer from diarrhea belongs to the group whose outcome is $\geq$ Rp. $1,668,700$ for about 55 people $(56.1 \%)$, whereas toddlers experiencing diarrhea incidence mostly reside in group whose income of family $<$ Rp. $1,668,700$ for about 57 people (55.9\%). Most of the children under five suffered from low social capital (39.9\%), 
Journal of Epidemiology and Public Health (2018), 3(3): 323-330

https://doi.org/10.26911/jepublichealth.2018.03.03.03

while those without diarrhea were the highest in the high social capital group (77.8\%).

2. Bivariate analysis determinant of diarrhea occurrence

Bivariate analysis was used to observe independent variables (family size, maternal knowledge, maternal healthy behavior, and environmental sanitation) with the dependent variable (diarrhea occurrence). The result of bivariate analysis can be seen in Table 2.

Table1. Sample Characteristics

\begin{tabular}{|c|c|c|c|c|c|c|}
\hline \multirow{3}{*}{ Subject Characteristics } & \multicolumn{4}{|c|}{ Diarrhea Case } & \multirow{2}{*}{\multicolumn{2}{|c|}{ Total }} \\
\hline & \multicolumn{2}{|c|}{ no diarrhea } & \multicolumn{2}{|c|}{ diarrhea } & & \\
\hline & $\mathrm{n}=100$ & $\%$ & $n=100$ & $\%$ & $\mathbf{n}=\mathbf{2 0 0}$ & $\%$ \\
\hline \multicolumn{7}{|l|}{ Children age } \\
\hline$<24$ months & 21 & 33.3 & 42 & 66.7 & 63 & 100 \\
\hline$\geq 24$ months & 79 & 57.7 & 58 & 42.3 & 137 & 100 \\
\hline \multicolumn{7}{|l|}{ Mmaternal education } \\
\hline$<$ Senior high school & 39 & 41.9 & 54 & 58.1 & 93 & 100 \\
\hline$\geq$ Senior high school & 61 & 57 & 46 & 43 & 107 & 100 \\
\hline \multicolumn{7}{|l|}{ Family Income } \\
\hline$<\operatorname{Rp} 1,668,700$ & 45 & 44.1 & 57 & $55 \cdot 9$ & 102 & 100 \\
\hline$\geq \operatorname{Rp} 1,668,700$ & 55 & 56.1 & 43 & 43.9 & 98 & 100 \\
\hline \multicolumn{7}{|l|}{ Social Capital } \\
\hline Low & 23 & 37.1 & 39 & 62.9 & 62 & 100 \\
\hline High & 77 & 55.8 & 61 & 44.2 & 138 & 100 \\
\hline
\end{tabular}

Table 2. Bivariate Analysis of Determinants of Diarrhea Occurrence

\begin{tabular}{|c|c|c|c|c|c|c|c|c|c|}
\hline \multirow{3}{*}{ Variable } & \multicolumn{4}{|c|}{ Diarrhea Case } & \multirow{2}{*}{\multicolumn{2}{|c|}{ Total }} & \multirow{3}{*}{ OR } & \multirow{3}{*}{$\underset{\mathbf{C I}}{\mathbf{9 5 \%}}$} & \multirow{3}{*}{$\mathbf{p}$} \\
\hline & \multicolumn{2}{|c|}{ no diarrhea } & \multicolumn{2}{|c|}{ diarrhea } & & & & & \\
\hline & $\mathbf{n}$ & $\%$ & $\mathbf{N}$ & $\%$ & $\mathbf{N}$ & $\%$ & & & \\
\hline \multicolumn{10}{|l|}{ Family size } \\
\hline$\leq 4$ & 54 & 59.3 & 37 & 40.7 & 91 & 100 & \multirow[t]{2}{*}{1.9} & $1.1-$ & \multirow{2}{*}{0.016} \\
\hline$>4$ & 46 & 42.2 & 63 & 57.8 & 109 & 100 & & 3.5 & \\
\hline \multirow{2}{*}{\multicolumn{10}{|c|}{$\begin{array}{l}\text { Maternal } \\
\text { knowledge }\end{array}$}} \\
\hline & & & & & & & & & \\
\hline Poor & 21 & 22.6 & 72 & 77.4 & 93 & 100 & \multirow[t]{2}{*}{0.1} & $0.1-$ & \multirow{2}{*}{$<0.001$} \\
\hline Good & 79 & 73.8 & 28 & 26.2 & 107 & 100 & & 0.2 & \\
\hline \multicolumn{10}{|c|}{$\begin{array}{l}\text { Maternal healthy } \\
\text { behavior }\end{array}$} \\
\hline Poor & 11 & 16.9 & 54 & 83.1 & 65 & 100 & \multirow[t]{2}{*}{0.1} & $0.1-$ & \multirow{2}{*}{$<0.001$} \\
\hline Good & 89 & 65.9 & 46 & 34.1 & 135 & 100 & & 0.2 & \\
\hline \multicolumn{10}{|l|}{$\begin{array}{l}\text { Enviroment } \\
\text { sanitation }\end{array}$} \\
\hline High & 16 & 22.2 & 56 & 77.8 & 72 & 100 & 0.2 & $0.1-$ & \\
\hline Low & 84 & 65.6 & 44 & 34.4 & 128 & 100 & & 0.2 & $<0.001$ \\
\hline
\end{tabular}

3. Multivariate analysis with multilevel approach

Multivariate analysis describes the effect of more than one independent variable to one dependent variable. The method used is multilevel logistic regression was STATA 13 progam.
Table 3 shows that the number of family members $>4$ people $(b=1.09 ; 95 \%$ $\mathrm{CI}=0.02$ to $2.15 ; \mathrm{p}=0.046)$ increased the risk of diarrhea. Good maternal knowledge $(b=-2.30 ; 95 \% \mathrm{CI}=-3.46$ to $-0.70 ; \mathrm{p}=$ o.oo3), good maternal behaviour $(\mathrm{b}=$ 2.09; $95 \% \mathrm{CI}=-3.47$ to $-0.70 ; \mathrm{p}=0.003$ ) 
and good environmental sanitation $(\mathrm{b}=$ $1.64 ; 95 \% \mathrm{CI}=-2.83$ to $-0.43 ; \mathrm{p}=0.003$ ) reduced the risk of diarrhea in infants.

In the data analysis, the ICC results were $66.14 \%$. It shows that the variation of diarrhea incidence which was about $66.14 \%$ is determined by the variable at the village level. This figure is bigger than the standard role of thumb size of $8-10 \%$ then the contextual influence shown from the multilevel analysis is very important to be taken into account. In the table, it is also shown that $\mathrm{p}<0.001$. This means that multilevel models differ statistically significant from ordinary logistic regression models.

\section{Table 3. Results of multilevel logistic regression determinant of diarrhea in} infants in Surakarta

\begin{tabular}{|c|c|c|c|c|}
\hline \multirow[b]{2}{*}{ Diarrhea Case/Incidents } & \multirow[b]{2}{*}{ b } & \multicolumn{2}{|c|}{$95 \%$ CI } & \multirow[b]{2}{*}{$\mathbf{p}$} \\
\hline & & $\begin{array}{c}\text { Lower } \\
\text { limit }\end{array}$ & $\begin{array}{c}\text { Upper } \\
\text { limit }\end{array}$ & \\
\hline \multicolumn{5}{|l|}{ Fixed Effect } \\
\hline The number of family member $>4$ & 1.09 & 0.02 & 2.15 & 0.046 \\
\hline Good maternal knowledge & -2.30 & -3.46 & -1.14 & $<0.001$ \\
\hline Good behavior & -2.09 & -3.47 & -0.70 & 0.003 \\
\hline Good environmental sanitation & -1.64 & -2.83 & -0.43 & 0.003 \\
\hline \multicolumn{5}{|l|}{ Random Effect } \\
\hline Village & 6.42 & 1.99 & 20.81 & \\
\hline \multicolumn{5}{|l|}{ n observasi $=250$} \\
\hline \multicolumn{5}{|l|}{ Log likelihood = - 70.77} \\
\hline LR test vs. logistic regression, $\mathrm{p}<0.001$ & & & & \\
\hline $\mathrm{ICC}=66.14 \%$ & & & & \\
\hline
\end{tabular}

\section{DISCUSSION}

\section{The effect of family size on the occurrence of diarrhea}

The results or this study showed that family size $\geq 4$ increased the risk of diarrhea. This study is consistent with Okour et al. (2012), which stated that family size is one of the determinants of risk factors for diarrhea.

Based on a study conducted by Mohammed and Tamiru (2014), it showed that households that have family members greater than 5 people are at high risk of diarrhea. Susanti et al. (2016) found that occupancy density $>4$ persons in the household greatly affected the susceptibility of children under five suffering from diarrhea because diarrhea is a contagious disease that not only occurs in infants but also occurs in adults. If an adult in a household has diarrhea, a toddler living in the same household is at risk for diarrhea.

\section{The effect of maternal knowledge on the occurrence of diarrhea}

The results of this study indicate that good maternal knowledge reduced the risk of diarrhea in children under five.

Maternal knowledge remains as a strong predictor of diarrhea morbidity. Lack of knowledge of mothers about healthy life is a risk factor that causes diarrhea in infants (Merga and Alemayehu, 2015).

According to a study conducted by Mukhtar et al. (2011), it was concluded that poor maternal knowledge about the dangers of diarrhea and its treatment caused the child severe dehydration during diarrhea. This is supported by the results of a study by Mumtaz et al. (2014) which indicates that the lack of knowledge of mothers about the dangers of diarrhea leads to a lack of attitudes and practices in prevention and appropriate treatment in case of diarrhea. Therefore, there is a need for maternal 
Journal of Epidemiology and Public Health (2018), 3(3): 323-330

https://doi.org/10.26911/jepublichealth.2018.03.03.03

health education about diarrhea to prevent immediate prevention if exposed to diarrhea.

This result is consistent with a study conducted by Desta et al. (2017), which stated that maternal knowledge is significantly associated with diarrheal cases. Maternal knowledge of diarrhea is directly related to the level of education, employment and information.

\section{The effect of maternal healthy be- havior on the occurrence of diarrhea}

The results of this study indicate that there is an effect of diarrhea prevention behavior on the occurrence of diarrhea. Mothers who have a toddler with good behavior have an effect on reducing the incidence of diarrhea, while the mother of underfives with bad behavior have an effect to increase the risk of diarrhea in the children.

Behavioral factors that can cause and increase the risk of diarrhea in infants include defecating, using contaminated drinking water, not washing hands after defecating and disposing of feces properly, not exclusively breastfeeding (milk) does not provide measles immunization for children under five, as well as waste disposal behavior (Mengistie et al., 2013; George et al., 2014; Thiam et al., 2017). Hand washing habits have a significant relationship with the incidence of diarrhea. Washing hands with soap, especially after defecation, after disposing of feces, before preparing food, before feeding the child and before meals has an impact in reducing the incidence of diarrhea (Rohmah and Syahrul, 2017).

\section{The effect of environmental sani- tation on the diarrhea occurrence}

This study also resulted in the finding that there is an effect of environmental sanitation on the incidence of diarrhea in children under five. Children with good environmental sanitation have a lower risk of having diarrhea from those with less environmental sanitation.

Study conducted by Imada et al. (2016), analyzed the relationship of environmental sanitation with the occurrence of diarrhea in the Amazon. The result shows that there was a decrease in the prevalence of diarrhea from $45.1 \%$ to $35.4 \%$ with the improvement of sanitation.

This finding is in line with the study of Roman et al. (2017) which stated that diarrhea risk factors include poor sanitation, unsafe water supply and improper environmental hygiene. Mukti et al. (2016) showed that there were still households using latrines without septic tanks. In latrines that do not have septic tanks, feces can seep into the soil around the toilet and contaminate the water source. Fecal exhausted feces around the house cause unpleasant odor and are infested with flies, thus becoming a source of diarrhea transmission.

Consuming unhygienic drinking water increases the risk of diarrhea in children (Hasan and Richardson, 2017). The study of Samwel et al. (2014) suggests that household characteristics that have a statistically significant effect on the incidence of diarrhea in children include the source of drinking water. This is in line with a study of Bitew et al. (2017) indicating that the use of unprotected unprotected water sources and inadequate drinking water services increase the risk of diarrhea in toddlers.

Zeleke and Alemu (2014) showed that household waste management is one of diarrhea risk factors. Handling methods and types of waste collection in households that are not sanitary is an environmental exposure to the incidence of diarrhea in infants. This is in line with the results of Thiam et al. (2017) study stating that the use of open pockets for storing household 
waste and disposing of household waste has a significant relationship to the incidence of diarrhea.

\section{The effect of village level on the diarrhea occurrence}

The results showed that the variation of diarrhea incidence which was $66.14 \%$ is determined by the variables at the village level, so it is important to be taken into account.

The low quality of the environment is a potential condition for the transmission of diarrheal diseases (Patil et al., 2014). Slum environmental conditions are at high risk of diarrheal cases due to poor housing and facility sanitation (Adane et al., 2017).

\begin{tabular}{l}
\hline REFERENCES \\
\hline Adane M, Mengistie B, Kloos H, Medhin G, \\
Mulat W (2017). Sanitation facilities, \\
hygienic conditions, and prevalence of \\
acute diarrhea among under-five \\
children in slums of Addis Ababa, \\
Ethiopia: Baseline survey of a longi- \\
tudinal study. PLoS ONE 12(8): eo1- \\
82783. https://doi.org/10.1371/jour- \\
nal.pone.o182783.
\end{tabular}

Bitew BD, Woldu W, Gizaw Z (2017). Childhood diarrheal morbidity and sanitation predictors in a nomadic community. Italian Journal of Pediatrics: 18. doi: 10.1186/s13052-017-0412-6.

Centers for Disease Control and Prevention (2015). Diarrhea: Common Illness, Global Killer.

Dinkes Kota Surakarta (2017) Profil Kesehatan 2016 Kota Surakarta.

Dinkes Provinsi Jateng (2017). Profil Kesehatan Provinsi Jawa Tengah Tahun 2016. Semarang.

Desta BK, Assimamaw NT, Ashenafi TD (2017). Knowledge, Practice, and Associated Factors of Home-Based Management of Diarrhea among Caregivers of Children Attending Un-
der-Five Clinic in Fagita Lekoma District, Awi Zone, Amhara Regional State, Northwest Ethiopia, 2016. Nurs Res Pract. doi: 10.1155/2017/8084548.

Fauziah A, Ahmad LAI, Tina L (2016). Studi Komparatif Determinan Kejadian Diare Di Wilayah Pesisir (Puskesmas Abeli ): 1-13.

George CM, Perin J, de Calani KJN, Norman WR, Perry H, Davis TP, Lindquist ED (2014). Risk Factors for Diarrhea in Children under Five Years of Age Residing in Peri-urban Communities in Cochabamba, Bolivia. Am J Trop Med Hyg. 91(6): 1190-1196.

Habit RBH (2017). Hubungan kebiasaan cuci tangan dan penggunaan jamban sehat dengan kejadian diare balita. 95-106. doi: 10.20473/jbe.v5i1.

Hasan M, Richardson A (2017). How sustainable household environment and knowledge of healthy practices relate to childhood morbidity in South Asia: analysis of survey data from Bangladesh, Nepal and Pakistan. BMJ Open. 7:e015019. doi: 10.1136/bmjopen-2016-015019.

Imada KS, Muniz PT (2016). Socioeconomic, hygienic, and sanitation factors in reducing diarrhea in the Amazon. Rev Saude Publica. 50(77): 1-10.

Kemenkes RI (2016) Profil Kesehatan Indonesia 2015. Jakarta.

(2017) Data dan Informasi Kesehatan Profil Kesehatan Indonesia 2016. Jakarta.

Lowe B, Lohse A, Andresen V, Vettorazzi E, Rose M, Broicher W (2016). The Development of Irritable Bowel Syndrome: A Prospective CommunityBased Cohort Study. 1-10. doi: 10.1038/ajg.2016.255.

Mengistie B, Berhane Y, Worku A (2013). Prevalence of diarrhea and associated 
risk factors among children underfive years of age in Eastern Ethiopia: A Prevalence of diarrhea and associated risk factors among children under-five years of age in Eastern Ethiopia: A cross-sectional study. Open Journal of Preventive Medicine, 3, 446-453.

Maharani D, Yusiana MA (2013). Lack Of Mother's Personal Hygiene Related To Diarrhea. 6(1): 119-128.

Merga N, Alemayehu T (2015). Knowledge, Perception, and Management Skills of Mothers with Under-five Children about Diarrhoeal Disease in Indigenous and Resettlement Communities in Assosa District, Western Ethiopia. J Health Popul Nutr. 33(1): 20-30.

Mohammed S, Tamiru D (2014). The Burden of Diarrheal Diseases among Children under Five Years of Age in Arba Minch District, Southern Ethiopia, and Associated Risk Factors: A Cross-Sectional Study. International Scholarly Research Notices. http://dx.doi.org/10.1155/2014/654901.

Mukhtar A, Ibrahim M, Izham M, Pathiyil RS (2011). A survey of mothers' knowledge about childhood diarrhoea and its management among a marginalised community of Morang, Nepal. Australas Med J. 4(9): 474-479.

Mukti DA, Raharjo M, Dewanti NAY (2016). Hubungan Antara Penerapan Program Sanitasi Total Berbasis Masyarakat (Stbm) Dengan Kejadian Diare Di Wilayah Kerja Puskesmas. Jurnal Kesehatan Masyarakat (eJournal). 4(3). ISSN: 2356-3346.

Mumtaz Y, Zafar M, Mumtaz Z (2014). Knowledge Attitude and Practices of Mothers about Diarrhea in Children under 5 years. Journal of the Dow
University of Health Sciences Karachi. 8(1): 3-6.

Okour A, Al-ghazawi Z, Gharaibeh M (2012). Diarrhea Among Children and the Household Conditions in a LowIncome Rural Community in the Jordan Valley. J Med J. 46 (2):108117.

Patil SR, Arnold BF, Salvatore AL, Briceno B, Ganguly S, Colford JM Jr, Gertler PJ (2014). The Effect of India's Total Sanitation Campaign on Defecation Behaviors and Child Health in Rural Madhya Pradesh: A Cluster Randomized Controlled Trial. PLoS Med 11(8): e1001709. doi:10.1371/journal.pmed.1001709.

Pengembangan A, Keprofesian P (2011). Konsep Biopsikososial pada Keluhan Psikosomatik. 375-379.

Roman C, Solh T, Broadhurst M (2017) Infectious Diarrhea. Physician Assist Clin. 2(2017): 229-245. doi: 10.1016/j.cpha.2016.12.006.

Samwel M. et al. (2014). Determinants of diarrhea among young children under the age of five in Kenya, evidence from KDHS 2008-09', 28(2).

Susanti WE, Sunarsih E (2016).Determinant Of Diarrhea On Children Under Five Years In Indonesia (Advanced Analysis IDHS 2012) Jurnal Ilmu Kesehatan Masyarakat. 7: 64-72.

Thiam S. et al. (2017). Prevalence of diarrhoea and risk factors among children under five years old in Mbour, Senegal: a cross-sectional study. Infectious Diseases of Poverty: 1-12. doi: 10.1186/s40249-017-0323-1.

WHO (2017). Cholera. World Health Organization: Geneva.

Zeleke AT, Alemu ZA (2014) Determinants of Under-Five Childhood Diarrhea in Kotebe Health', 14(4). 